\title{
Efficacy of Trichogramma evanescens and Bacillus thuringiensis kurstaki to Control Lesser Date Moth Batrachedra amydraula Merck
}

Hussain Fadhil Alrubeai ${ }^{1}$, Bassim Shehab Hamad ${ }^{1}$, Ahmed Mushtaq Abdullatif ${ }^{1}$, Hani Zair Ali $^{2}$ and Ahmed Abed $^{1}$

1. Ministry of Science and Technology, Directorate of Agricultural Research, Integrated Pest Control Center, Iraq

2. Ministry of Agriculture, Directorate of Horticulture, Iraq

Received: February 6, 2014 / Published: April 20, 2014.

\begin{abstract}
Efficacy of the egg parasitoid, Trichogramma evanescens and the bio-pesticide bacteria, Bacillus thuringiensis kurstaki (Btk) in reduction of lesser date moth, Batrachedra amydraula infestations were studied during seasons of 2011 and 2012 . The result of 2011 showed that the release of egg parasitoid by rate of 500 and 1,000 parasitoids/palm tree achieved $55.06 \%$ and $67.45 \%$ reduction in infestation percentage, respectively. Meanwhile high reduction in infestation was achieved by Btk (78.65\%) at dose rate of $6 \mathrm{~g} \mathrm{Btk} \mathrm{powder} / \mathrm{kg}$ talc powder. The result of 2012 showed that the highest control efficacy (58.78\%) was achieved at the first time of the control process, using Btk at dose rate of $6 \mathrm{~g} / \mathrm{kg}$ talc powder. This result was not different significantly from the release of egg parasitoid by rate of 1,000 parasitoids/palm tree which achieved 53\% reduction in infestation percentage. At the second time (after one week from the first application), the efficacy of Btk at dose rate of $6 \mathrm{~g} / \mathrm{kg}$ talc powder was increased to $78.78 \%$, which differ significantly with the release of egg parasitoid by the same rate of 1,000 parasitoids/palm tree, having $61.79 \%$ efficacy. Reapplication of the control method achieved an increase in efficacy of the control agents, such increase was significant for both the release of the parasitoid at rate of 1,000/palm tree and for Btk at a dose of $6 \mathrm{~g} / \mathrm{kg}$ talc powder.
\end{abstract}

Key words: Lesser date moth, Batrachedra amydraula, Trichogramma evanescens, Btk.

\section{Introduction}

The date palm tree, Phoenix dactylifera especially its fruit plays an important role in the agricultural economy of many Iraq farmers, this tree is exposed to infestation by various kinds of insects and diseases. One of the most important insect species is the lesser date moth, Batrachedra amydraula Merck. This pest attacks date fruits since their early stage of maturity (chimmery stage), causing heavy losses in productivity. To reduce the impact of this pest, chemical control campaigns have been taken since long time [1], unfortunately without success. The trend at present however, is towards the use of safe

\footnotetext{
Corresponding author: Bassim Shehab Hamad, Ph.D., research fields: entomology and IPM. E-mail: bassim.shehab@yahoo.com.
}

and environmentally friendly control agents. Among those are the bio-pesticides bacteria, Bacillus thuringiensis and egg parasitoids. Oophagous Hymenoptera of the genus Trichogramma was used in many countries in biological control programs to regulate pest populations, mainly lepidopteron species $[2,3]$. One of well-known species is Trichogramma evanescens which is very effective and widely used in control programs of lepidopterous pests on many crops $[4,5]$. Meanwhile, the bacterial bio-insecticide, Bacillus thuringiensis kurstaki (Btk) is considered one of most powerful biocides and widespread to combat larvae of lepidopteron species [6, 7]. This study aimed to estimate the efficacies of Trichogramma evanescens and Btk in controlling the lesser date moth, Batrachedra amydraula. 


\section{Materials and Methods}

\subsection{Preparation of Bio-control Agents}

1-stock cultures of Trichogramma evanescens, were maintained on Sitotroga cerelella (Oliv.) and Ephestia cautella eggs killed by UV light. Adults were fed on a diluted honey solution ( $30 \%$ in water). Rearing was conducted in glass tubes $(2 \mathrm{~cm} \times 7 \mathrm{~cm})$ with the proportion of one female for 10 host eggs glued on cardboard. Rearing conditions were $25 \pm 1{ }^{\circ} \mathrm{C}, 75 \% \pm$ $5 \%$ relative humidity (R.H.), and 16-18 h light-dark regime.

2-Btk that was used was the commercial bacterial insecticide (Belthiul WP) $(32,000 \mathrm{IU} / \mathrm{mg})$, produced by the Probelte Fitocompan/Spanish.

\subsection{Field Experiments}

Field experiments were carried out in Al-Zaafaraniyah horticultural station, South East of Baghdad, in the first week of May of seasons 2011 and 2012, after fruits sitting of Zehdicultivar, which is more susceptible to this insect $[8,9]$, reach the chimmry stage as the following:

(1) The egg parasitoid: The parasitoid was released at rate of 500 and 1,000 parasitoids per palm tree with five replicates per treatment including the control treatment.

(2) Bacterial insecticide: The date fruit bunches were fully dusted by the bacterial pesticide at concentrations of $0.5,1,3$ and $6 \mathrm{~g} / \mathrm{kg}$ of talc powder in 2011, and with 1, 3 and $6 \mathrm{~g} / \mathrm{kg}$ talc powder in 2012 with five replicates (palm tree) per treatment including control treatment, which treated with talc powder only. The same treatments were repeated after one week from the first treatment.

The results were taken after seven days of each treatment by cutting five fruit strands after being placed in a paper bag, from each fruit bunch found on each treated tree, the samples brought to the lab to calculate the rate of infestation. The efficacy of the parasitoids and the bacterial treatments were estimated according to Hinderson-Telton equation [10], statistical analysis was carried out using randomized complete block design (RCBD) and Duncan test (SPSS version 20).

\section{Results and Discussion}

Preliminary results for the season of 2011 (Fig. 1) showed that the highest control percentage (78.65\%) of lesser date moth, Batrachedra amydraula infestation was achieved by bacterialbio-pesticide (Btk) at a dose of $6 \mathrm{~g} \mathrm{Btk/kg}$ talc powder however, it did not

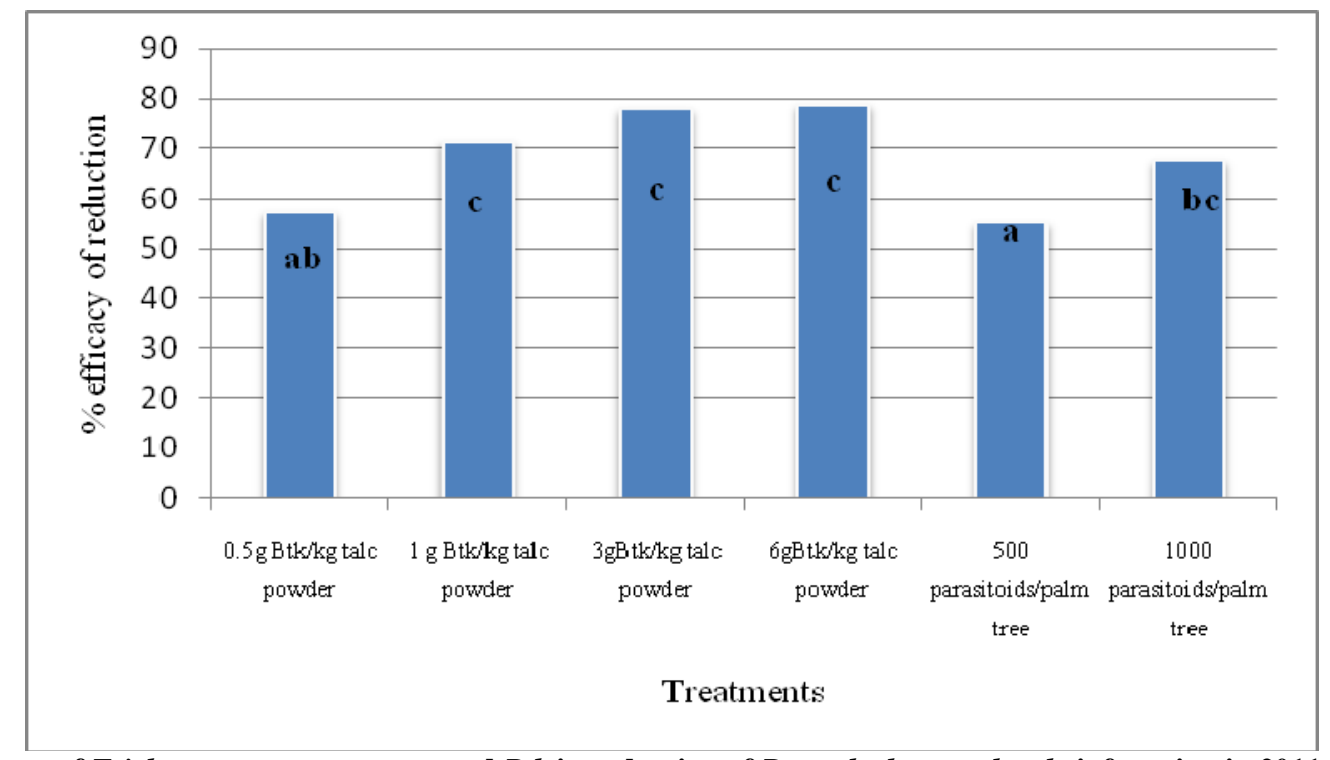

Fig. 1 Efficacy of Trichogramma evanescens and Btk in reduction of Batrachedra amydraula infestation in 2011 season. The same letters mean there is no significant difference between means of the columns according to Duncan test $(P \leq 0.05)$. 


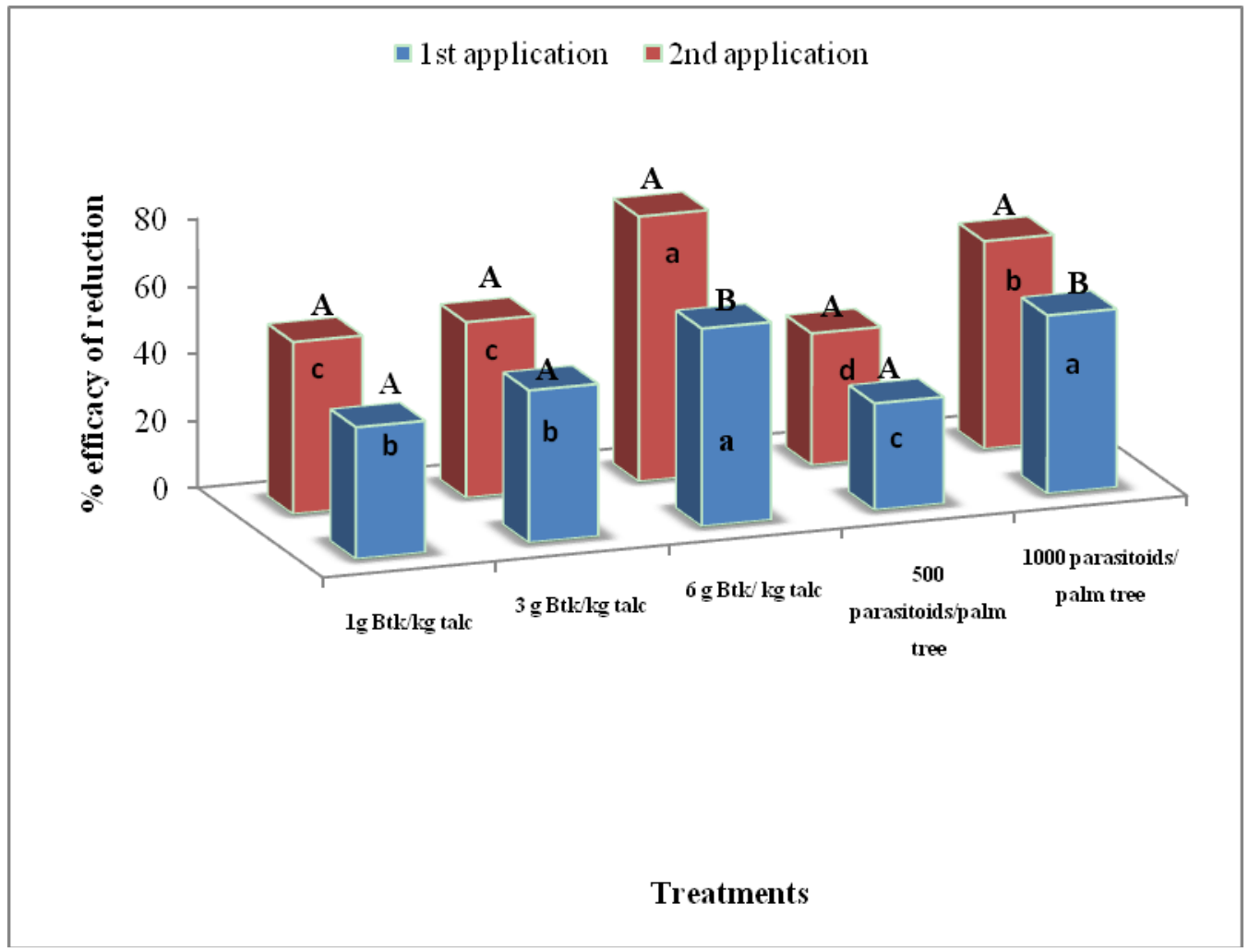

Fig. 2 Efficacy of Trichogramma evanescens and Btk in reduction of Batrachedra amydraula infestation in 2012.

The same small letters mean there is no significant differences between means in the same raw, the same capital letters mean there is no significant difference between means of the columns according to Duncan test $(P \leq 0.05)$.

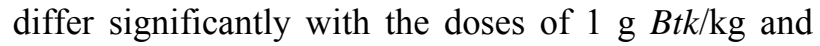
$3 \mathrm{~g} \mathrm{Btk} / \mathrm{kg}$ talc powder. The result also did not differ significantly with that achieved $(67.45 \%)$ by the release of parasitoids at rate of 1,000 parasitoids/palm tree. While, releasing parasitoid at the rate of 500 parasitoids/palm tree resulted in $55.06 \%$ control efficacy, without significant differences $(57.11 \%)$ with the use of bacterial bio-pesticideat dose of $0.5 \mathrm{~g}$ $B t k / k g$ talc powder.

Results of 2012 season (Fig. 2) showed that the control efficacy was increased with the increasing of Btk concentration used at the first (early) treatment in the season. The highest efficacy was $58.78 \%$ using $6 \mathrm{~g}$ $B t k / \mathrm{kg}$ talc powder. This did not differ significantly with the result (53\%) achieved by the release of $T$. evanescens at a rate of $1,000 /$ palm tree. Meanwhile, both of treatments differ significantly with $B t k$ at rate of $3 \mathrm{~g} / \mathrm{kg}$ talc powder which achieved $45.25 \%$ of control and the rate of $1 \mathrm{~g} \mathrm{Btk/kg}$ talc powder $(39.13 \%)$. In the second time treatment, the control efficacies were increased for both control agents. The bacterial bio-insecticide at concentration of $6 \mathrm{~g} \mathrm{Btk} / \mathrm{kg}$ talc powder achieved $78.78 \%$ control efficacy, which differ significantly with all other concentrations used. Followed by the release of $T$. evanescens at rate of 1,000/palm tree, which achieved $61.79 \%$.

Reapplication of the control method achieved an increase in efficacy of the control agents, such increase was significant for both the release of the parasitoid at rate of 1,000 parasitoids/palm tree and for Btk at a dose of $6 \mathrm{~g} / \mathrm{kg}$ talc powder. Using Trichogramma evanescens confirmed the efficacy of such good bio-rational agent to reduce the rates of infestations of lesser date moth in date palm orchards in El-Bahria Oases, Giza, Egypt [11]. Mohammad et al. [12] illustrated that infestation levels of lesser date moth in Al-Anbar Governorate, Iraq, were reduced significantly after two weeks of the release of 300 Trichogramma evanescens or T. principium/palm tree, with higher efficiency for T. evanescens. A proportion 
of lesser date moth control of $36.5 \%$ and $69 \%$ was achieved by using bacterial insecticide $B t k$ at rate of $150 \mathrm{~g} / 100 \mathrm{~L}$ water in New Vally, Egypt [13]. Annual report from Oman [14] revealed that the use of bacterial bio-pesticide Bt aizawai $10.3 \%$ gave the rate of $43.8 \%$ reduction in the infestation of lesser date moth after seven days of treatment and $60.8 \%$ after 14 days of treatment. Btk at rate of $1 \mathrm{~kg} / 100 \mathrm{~L}$ water was also used successfully in Saudi Arabia, with a volume of 3-7 L/palm tree to control this pest [15].

In conclusion, the results of this investigation depicted that using of Btk at rate of $6 \mathrm{~g} / \mathrm{kg}$ talc powder and/or release of Trichogramma evanescens at rate of 1,000 parasitoids/palm tree were a successful option to control the lesser date moth as alternative strategy to chemical control.

\section{References}

[1] A.A. Hussain, Date palms and dates with their pests in Iraq, Ministry of Higher Education and Scientific Research, University of Baghdad, Baghdad, Iraq, 1974.

[2] L.Y. Li, Worldwide use of Trichogramma for biological control on different crops: A survey, in: E. Wajnberg, S.A. Hassan (Eds.), Biological Control with Egg Parasitoids, London, International Organization for Biological Control, 1994, pp. 37-53.

[3] J.R.P. Parra, R.A. Zucchi, Trichogramma in Brazil: Feasibility of use after twenty years of research, Neotrop. Entomol. 33 (2004) 271-281.

[4] J.L. Shipp, K. Wang, Evaluation of commercially produced Trichogramma spp. (Hymenoptera: Trichogrammatidae) for control of tomato pinworm, Keiferia lycopersicella (Lepidoptera: Gelechiidae), on greenhouse tomatoes, Canadian Entomologist 130 (1998) 721-731.

[5] B.P. Mertz, S.J. Fleischer, D.D. Calvin, R.L. Ridgway, Field assessment of Trichogramma brassicae (Hymenoptera: Trichogrammatidae) and Bacillus thuringiensis for control of Ostrinia nubilalis (Lepidoptera: Pyralidae) in sweet corn, Journal of
Economic Entomology 88 (1995) 1616-1625.

[6] L.A. Lacey, R. Frutos, H.K. Kaya, P.V. Rool, Insect pathogens as biological control agents: Do they have a future?, Biol. Control 21 (2001) 230-248.

[7] N.A. Brodrick, R.M. Goodman, K.F. Raffa, J. Handelman, Synergy between Zwittermicin A and Bacillus thuringiensis sub sp. Kurstaki against gypsy moth (Lepidoptera: Lymantriidae), Environ. Entomol. 29 (2000) 101-107.

[8] F.M. Aziz, Biological and ecological studies on the lesser date moth Batrachedra spp. and predicting of its appearance infesting the date palm early in the spring, Ph.D. Dissertation, Baghdad University, 2005.

[9] T.R. Ahmad, H.F. Alrubeai, Bionomics of two species of Batrachedra amydraula and susceptibility of different varieties of dates to the species of amydraula, IPA J. Agri. Res. 6 (3) (1996) 203-212.

[10] C.F. Henderson, E.W. Telton, Tests of acaricides against the brown wheat mite, J. Econ. Entomol. 48 (2) (1955) 157-161.

[11] M.A. Ali, M.M. Metwally, A.E. Hussain, Release of Trichogramma evanescens (West) in date palm fields as an eco-biological agent for suppression insect's infestation in date palms and dates at El-Bahria Oases, Giza, Egypt, in: 1st Arab Conference of Applied Biological Pest Control, Cairo, Egypt, Apr. 5-7, 2004, pp. 16-17.

[12] J.K. Mohammad, A.A. Ali, R.F. Al-Jassani, M. El-Bouhssini, The use of the egg parasitoids Trichogramma evanescens Westwood and T. principium Sugonjaev \& Sorkina for the biological control of the lesser date moth Batrachedra amydraula Meyrick, Al-Anbar J. Agri. Sci. 9 (3) (2011) 292-303.

[13] A.A. Sayed, S.A. Temrak, P. Vergolus, Comparative performance of Batrachedra amydraula and the natural product spinosad for control the lesser date moth Batrachedra amydraula infesting date palm trees in New Valley, Egypt, 2001, Assiut. J. of Agric. Sci. 32 (3) 183-189.

[14] Evaluation of Some Pesticides against Lesser Date Moth Batrachedra amydraula, Agricultural and Livestock Research-Annual report, 2008, pp. 242-243.

[15] D.M. Habib, S.H. Essaadi, Biocontrol of the lesser date moth batrachedra amydraula meryrick (cosmopteridae = batrachedridae) on date palm trees, Acta. Hort. (ISHS) 736 (2007) 391-397. 